\title{
Integrated water management tools supporting future water security and food production in West Africa
}

\author{
HÈOU MALÉKI BADJANA ${ }^{1,2,3}$, JÖRG HELMSCHROT ${ }^{4,5}$, WOLFGANG-ALBERT \\ FLÜGEL ${ }^{2}$, KPÉRKOUMA WALA ${ }^{3}$, ABEL AFOUDA ${ }^{1}$ \& KOFFI AKPAGANA ${ }^{3}$ \\ 1 West African Science Service Center on Climate Change and Adapted Land Use, Graduate Research Program of \\ Climate Change and Water Resources, University of Abomey-Calavi, Cotonou, Benin \\ maleki.badi@,yahoo.fr \\ 2 Department of Geoinformatics, Hydrology and Modelling, Friedrich-Schiller University of Jena, Germany \\ 3 Laboratory of Botany and Plant Ecology, Faculty of Sciences, University of Lome, Togo \\ 4 Biodiversity, Evolution and Ecology of Plants (BEE), University of Hamburg, Germany \\ 5 Southern African Science Service Centre for Climate Change and Adaptive Land Management (SASSCAL)
}

\section{INTRODUCTION}

In most West African countries, the limited water resources are subject to several pressures including population growth and the associated increasing demand for water of sufficient quantity and quality for food production, changing land use and climate. Significant changes have occurred in land use and land cover (LULC) throughout the region, if compared to other environmental changes (Braimoh and Vlek 2004, Berger et al. 2006, Badjana et al. 2014). This calls for the integrated land and water resources management (ILWRM), an appropriate approach to strive for sustainable management of water resources and to adapt to global change impacts (Flügel 2010). Thus, the integrated assessment of surface and subsurface water resources based on a holistic systems's analysis approach (Flügel 2010) is essential to develop adequate management responses. However, the implementation of this approach is difficult in a region facing a lack of accurate and representative available data, limited knowledge and adequate technologies. Adapted technologies, techniques and practices are therefore required to overcome these difficulties and reduce the uncertainties related to future water availability and demand. This paper presents methodologies and tools that are in development and application, all supporting sustainable water management and food production in West Africa.

\section{ILWRM IN WEST AFRICA}

Considerable efforts were made in West Africa towards sustainable water management by implementing IWRM plans (GWP 2004). However, the enhancement of IWRM to ILWRM, which particularly recognizes the consideration of LULC-related aspects and which are insufficiently integrated into management efforts until now (Calder 2005), is still needed. Also, little emphasis has been given to climate change impact and mitigation studies at the regional or transboundary scale, nor were they addressed in national adaption plans accordingly. This is mainly due to a lack of (1) appropriate assessment scales (river/lake basin, groundwater aquifer), (2) transboundary coverage and integration, (3) collaboration between researchers, countries and decision makers, (4) available data and monitoring systems, and (5) research capacities. The WASCAL (West African Science Service Center on Climate Change and Adapted Land Use; www.wascal.org) program, funded by the Federal Ministry of Education and Research (BMBF) of Germany addresses such challenges by developing and merging capacities in ten West African countries (Togo, Benin, Burkina-Faso, Ghana, Senegal, Mali, Niger, Nigeria, Côte d'Ivoire, The Gambia).

\section{BASIN ASSESSMENTS}

As underlined by GWP (2004), the basin is the basic planning and management unit and appropriate ILWRM should take place at the basin scale, whether for the local catchment or aquifer, or a transboundary river basin. Although some successful applications were conducted (e.g. GLOWA-Volta project, www.glowa.org), there are still major sub-catchments that are not yet investigated. Comparable hydrological assessments at smaller scale are necessary to better 
understand system functioning and to reduce uncertainties. Thus, efforts should be undertaken to assess a catchment's characteristics and its rainfall and runoff dynamics that can be categorized into three basic approaches of: (1) baseflow separation, (2) frequency analysis and (3) recession analysis (Brodie and Hostetler 2005), all allowing for better understanding of the system functioning (e.g. timing and spatial pattern, floods, risks, groundwater dynamics etc.).

\section{APPLICATION OF GEOINFORMATION TECHNOLOGIES FOR WATER RESOURCES MODELLING AND IMPACTS AND VULNERABILITY ASSESSMENT}

The lack of representative hydro-meteorological time series and landscape information, and the complex climatic systems in West Africa call for the application of geoinformation technologies for an integrated water resources assessment. This includes remote sensing and GIS, climate and distributed hydrological models and decision support systems (Berger et al. 2006, McCartney et al. 2012). The integration of such tools helps to account for missing environmental data, the special landscape heterogeneity, the integrated and multi-scale river basin systems dynamics analysis, uncertainties reduction and decision making on the prediction and sustainable management of water resources. Applying the Integrated Land Management System (ILMS), a modular software platform that integrates remote sensing, GIS, distributed hydrological models and DSS, a pilot study regarding the implementation of ILWRM is currently being undertaken in the Kara River basin (Badjana et al., 2014), a sub-catchment of the Volta basin.

\section{INTEGRATION OF SOCIO-ECONOMIC DRIVERS}

As socio-economic data provide adequate information on population growth, i.e. demands and supply of water (Osei Asare 2004), appropriate ILWRM should integrate socio-economic factors that support the understanding of relevant system drivers and pressures and their impact on current and future water resources. For example, the spatially explicit multi-agent programming models that facilitate the integration of biophysical and socio-economic processes at a spatially disaggregated level of analysis (Berger et al. 2006) are useful tools for assessment studies.

\section{CONCLUSION AND OUTLOOK}

A pre-requisite for a sustainable water management and food production in West Africa is an integrated and science-based assessment of existing and future water resources. Besides climaterelated impacts, land use and management are of high relevance for a reliable integrated water system assessment and analysis. Given the wide range of applicable methods and tools to overcome data gaps, the ILWRM must be further supported by up-to-date technologies, but also integrated into adaptation and actions plans to ensure sustainable water security and food production in West African river basins.

Acknowledgements This work has been funded by the Federal Ministry of Education and Research (BMBF) of Germany through the West African Science Service Center on Climate Change and Adapted Land Use (WASCAL).

\section{REFERENCES}

Badjana, H. M., et al. (2014) Assessment of land-cover changes in a subcatchment of the Oti basin (West Africa): A case study of the Kara River basin. Zentralblatt für Geologie und Paläontologie Teil I 1, 151-170.

Berger, T., et al. (2006) Sustainable water use under changing land use, rainfall reliability, and water demands in the Volta basin (GLOWA Volta). IHDP Newsletter 6, 14-15

Braimoh, A.K. and Vlek, P.L.G. (2004) Land-cover change analysis in the Volta basin of Ghana. Earth Interactions 8(21), 1-16.

Flügel W.-A. (2011) River basin impact assessment of changing land use and climate by applying the ILWRM approach in Asia, Africa and Europe. 25p.

Global Water Partnership (GWP) (2004) Integrated Water Resources Management (IWRM) and Water Efficiency Plans by 2005 Why, What and How? Sweden, 45p. ISSN: 1403-5324, ISBN: 91-974559-5-4

McCartney, M., et al. (2012) The water resource implications of changing climate in the Volta River Basin. Colombo, Sri Lanka: International Water Management Institute (IWMI). 40p. (IWMI Research Report 146). doi:10.5337/2012.219.

Osei Asare, Y. B. (2004) Household water security and water demand in the Volta Basin of Ghana. PhD Thesis, 164p. University of Ghana, Lagon-Accra, Ghana. 